\title{
Sectorial specialisation in East Asia and Latin America compared
}

\author{
Especialização setorial comparada no \\ Leste Asiático e América Latina
}

MARCELA MIOZZO*

RESUMO: Os países do leste asiático foram bem-sucedidos em se especializar em máquinas e bens de capital. Os países latino-americanos, por outro lado, se retiraram desses setores, reforçando sua especialização em bens intensivos em recursos. Os arranjos institucionais em vigor nas duas regiões explicam essas divergências. Em particular, as diferenças na estratégia e estrutura das empresas líderes, a natureza da promoção industrial por parte do governo, o desenvolvimento e o apoio de pequenas e médias empresas e a operação de empresas estrangeiras podem explicar o sucesso e o fracasso respectivos na especialização setorial em máquinas. O não desenvolvimento desses setores pode atrapalhar o processo de desenvolvimento econômico.

PALAVRAS-CHAVE: Extremo Oriente, América Latina, bens de capital, empresas.

ABSTRACT: East Asian countries have been successful at specialising in machinery and capital goods. Latin American countries, on the other hand, have retreated from these sectors, reinforcing their specialisation in resource-intensive goods. Institutional arrangements in place in both regions explain these divergences. In particular, the differences in the strategy and structure of leading firms, the nature of industrial promotion by the government, the development and support of small and medium-sized firms and the operation of foreign-owned firms may explain the respective success and failure in sectoral specialisation in machinery. Failure to develop these sectors may hinder the process of economic development.

KEYWORDS: East Asia, Latin America, capital goods, companies.

JEL Classification: O53, O54, L6.

\footnotetext{
* School of Management, University of Manchester Institute of Science and Technology - UMIST, Manchester, UK. E-mail: marcela.miozzo@manchester.ac.uk; Orcid: 0000-0002-5978-9953.
} 


\section{INTRODUCTION}

East Asia and Latin America have diverged greatly since the 1970s. East Asian countries have been successful at specialising in machinery and transport equipment sectors, which have become the fastest growing category in world exports. Latin American countries, instead, have experienced an 'involution' of prototypical import substitution industries (such as metal manufactures and machinery sectors and consumer durable goods) towards the production of industrial inputs that exploit natural resources. The recurrent debates about alternative trade policies can not explain these structural changes and their implications for industrial growth.

Traditional development literature misrepresents industrialisation as a process of accumulating technology largely embodied in physical capital, rather than focusing on the institutional structures required to manage technological and organisational changes (Lall, 1987; Fransman and King, 1984). For example, the traditional choiceof-techniques literature (Hayami and Ruttan, 1971) only concentrates on the static problem of optimising between techniques with different capital/labour ratios. Similarly, the transfer-of-technology literature (Bhalla, 1979; Stewart, 1978) concerns itself only with the cost, suitability and effectiveness of the technology transferred.

This hinders efforts to explain national specialisation in less developed countries (LDCs) and how countries may swing from one sectoral specialisation to another. A more fruitful approach involves bringing together insights from nontraditional development literature and studies of technology. In particular, a number of recent studies demonstrate a close link between institutional arrangements and a country's capacity to specialise in machinery and capital goods. Among nontraditional development theorists, there appears to be a consensus that these sectors are critical for development because of the interdependence and linkages across the production process. While the particular institutional arrangements may promote or impede a country's specialisation in machinery sectors, failure to develop these sectors may hinder the process of industrial development.

This paper addresses these issues through a comparison of three East Asian countries - Korea, Taiwan and Hong Kong - and three Latin American countries - Brazil, Argentina and Mexico. Drawing on a range of data, the paper demonstrates that the degree of success in industrialisation is interlinked with diverging paths of sectoral specialisation, which, in turn, reflects specific features of the different national institutional arrangements.

This paper is organised as follows. Section 1 examines the importance of machinery and capital goods sectors for economic development and assesses the link between particular institutional arrangements and the successful development of these sectors. Section 2 illustrates the changing sectoral specialisation in production and trade in East Asia and Latin America. Section 3 explains these differences in terms of prevailing institutional arrangements. A conclusion draws implications for research and policy. 


\section{INSTITUTIONS AND THE DEVELOPMENT OF MACHINERY SECTORS}

Historians and students of technological change stress the importance of machinery sectors for economic development. Although traditional industries such as textiles may play an important role in early stages of industrialisation, thereafter, fast growth is linked to pervasive technologies. In the case of USA and Germany in the late nineteenth and early twentieth century, this was electrical machinery and chemicals and, in the case of Japan, Korea and Taiwan in the post-war, this is electronic capital goods, electronic components and telecommunications equipment (Perez, 1985; Soete, 1985).

Among non-traditional development theorists, there also appears to be a consensus that machinery and capital goods sectors are critical for economic development because of the interdependence and linkages along the production process (Hirschman, 1958; Fransman and King, 1984). Without a domestic capability in the production of capital goods - machinery, machine tools, etc. - every other sector is thoroughly dependent on imported goods and imported technology. These sectors also require broad skills, which provide the conditions necessary to adapt and improve products and processes on the shopfloor. This enables learning from foreign technology and the development of indigenous technological capability (Amsden, 1989).

However, specialisation in the production of machinery is difficult. One indication of this is a particular version of the Leontief paradox - that labour productivity differentials in comparable plants in LDCs and developed countries tend to be smaller in machine-paced or process-centred sectors than in operator-controlled or product-centred sectors, even when similar techniques are used in both countries (Hirschman, 1958). For LDCs, the advantage of process-centred industries is that (although they tend to be more capital-intensive) there are basic processes around which work is organised almost naturally (as in smelting, petroleum refining and brewing). On the other hand, in product-centred sectors such as machinery, work is not organised around one or several key technical processes. It depends rather on the assembly of a hierarchy of components, and coordination between firms.

The technological imperatives in the case of process-centred industries are an aid to the co-ordination of the production process and to management in order to evaluate plant performance. In product-centred sectors, sequences are less rigid and there is a greater need for organisational and management coordination of plant and office and inter-firm operations. Hirschman mentions difficulties in management and industrial relations, including excessive centralisation of authority and ineffective work co-ordination, and difficulties in carrying out functions not directly connected with the central production process, such as planning, accounting and maintenance, as among the key institutional shortcomings in LDCs (Hirschman, 1958, p.136).

This suggests that the institutional structures in which firms and markets are embedded make a difference to the development of certain industrial sectors. Indeed, while sectors may be subject to a particular technological and market logic 
(barriers to entry, trade-offs that firms confront between capital and labour intensity, composition of labour force, concentration, vertical integration, minimum scale of production and scope of product range, and reliance on internal labour markets), institutional arrangements will have an important effect on a sector's economic performance.

In particular, differences in incentive structure facing economic actors, in internal organisation, competences and strategies of leading business firms, and other institutions in which agents are embedded and which constrain and guide microeconomic coordination and change - state promotion and regulation, the extent to which firms and workers may benefit from involvement in dense 'networks' of privileged, preferential trading relations, which may include smaller firms and relations with foreign-owned firms - will all affect the development of certain industries (Hollingsworth et al., 1994). Moreover, firms within successful sectors are often concentrated within specific regions where they are covered by similar governance arrangements allowing them to utilise similar skills, rely on the same kind of educational and research institutions and benefit from communication with competitors, and close relations with suppliers and customers (Porter, 1990). A country whose institutional arrangements disadvantage firms under given conditions of international competition may not be able to learn and develop its technological and organisational capability necessary to sustain a machinery sector and may experience sectoral deindustrialisation.

Also, the development of the machinery sector is an important support for newer developments in, for example, electronics and the computer industry. The case of East Asia shows that the route to advanced electronics and information technology was not by "leapfrogging" but through a painstaking and cumulative learning process in the mechanical, electromechanical and precision engineering activities (Hobday 1995a; 1995b). An implication of this is that the building of an electronics and computer industries requires human resources across basic craft, technician, engineering and industrial skills, rather than the software and computer-based skills normally associated with information technology (see also Evans and Tigre 1993). The next section illustrates the growing divergences between East Asian and Latin American countries in terms of sectoral specialisation in production and trade. Indeed, East Asian countries have deepened their specialisation in machinery and transport equipment sectors while Latin American countries have retreated progressively from these sectors and specialised in the production of resource-intensive intermediate goods.

\section{SPECIALISATION IN PRODUCTION AND TRADE IN EAST ASIA AND LATIN AMERICA}

In this section we draw on comparable empirical data to show how East Asia and Latin America have diverged in the impact on and evolution of production and trade specialisation patterns in the last decades. Figures 1 to 4 demonstrate 
Figure 1: Korea: Industrial structural change 1980-1985-1990

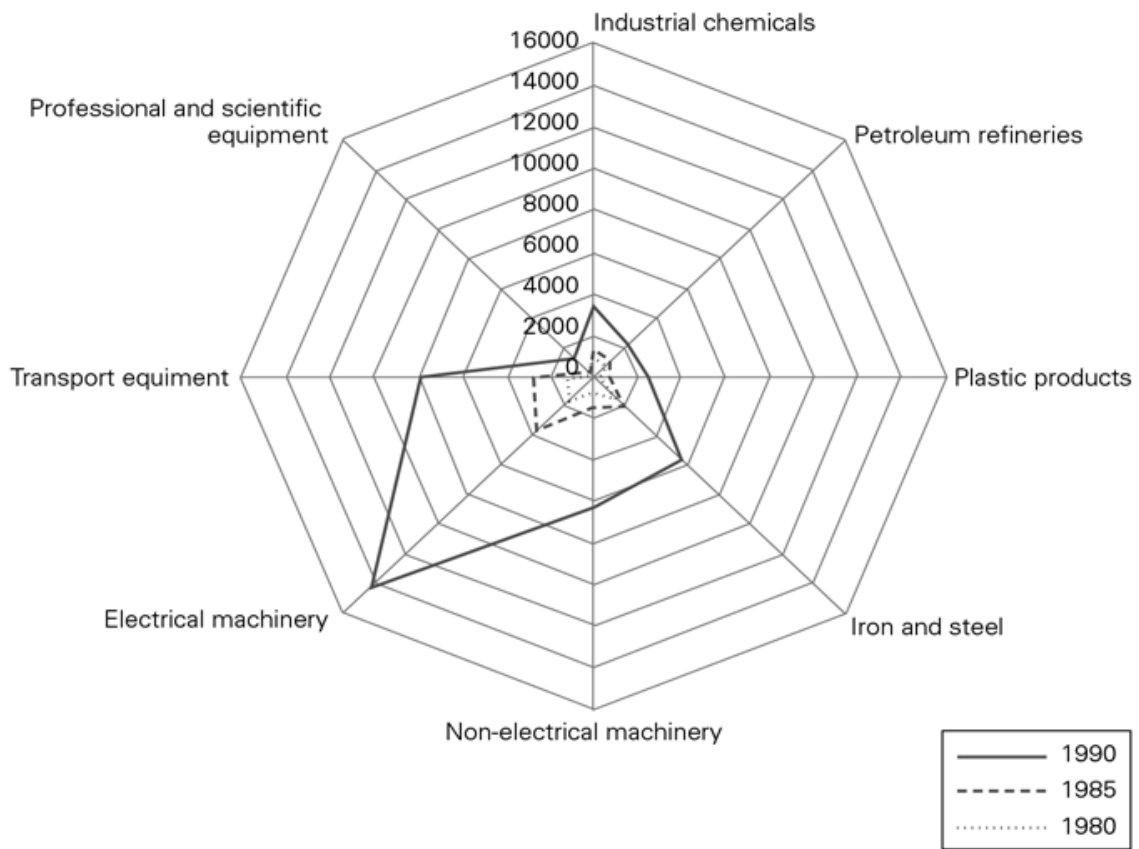

Figure 2: Argentina: Industrial structural change 1980-1985-1990

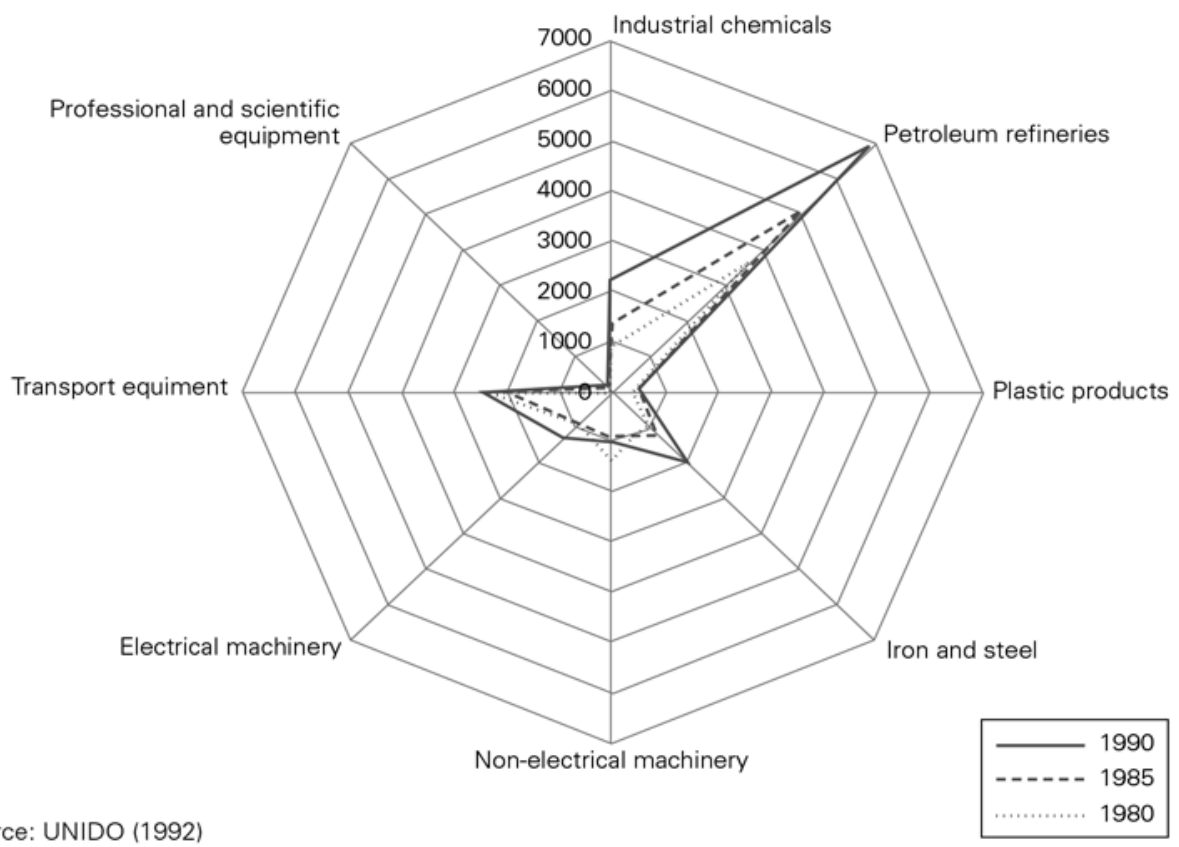


Figure 3: Brazil: Industrial structural change 1980-1985-1990

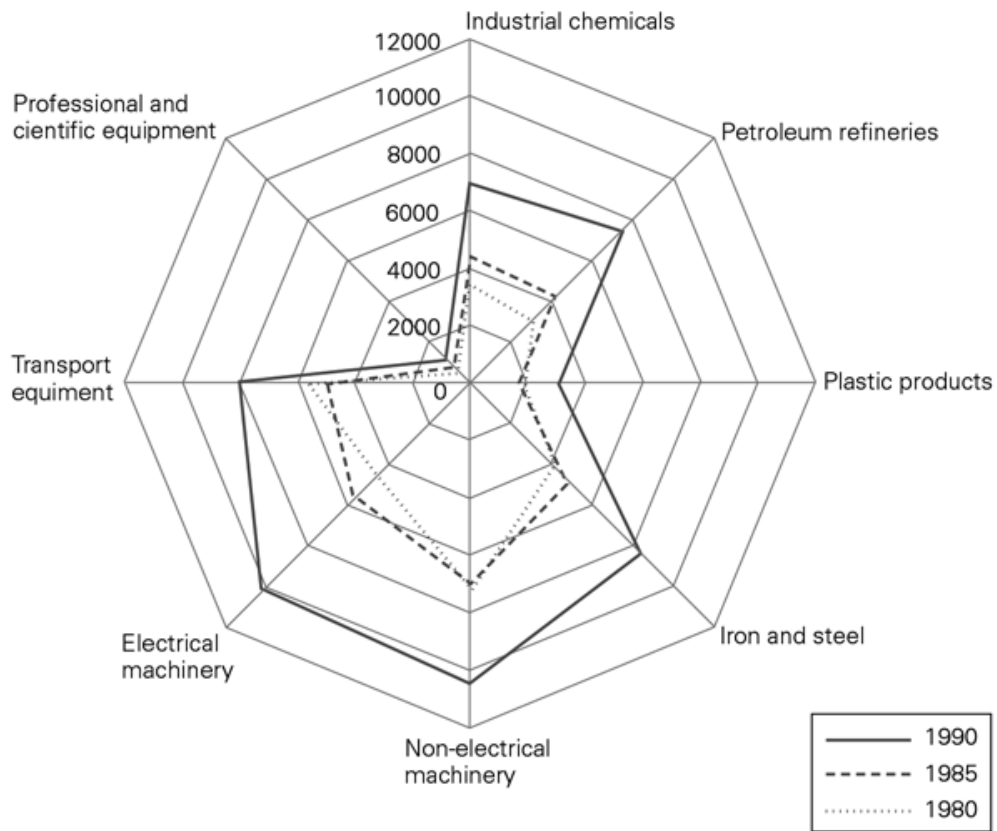

Figure 4: Mexico: Industrial structural change 1980-1985-1990

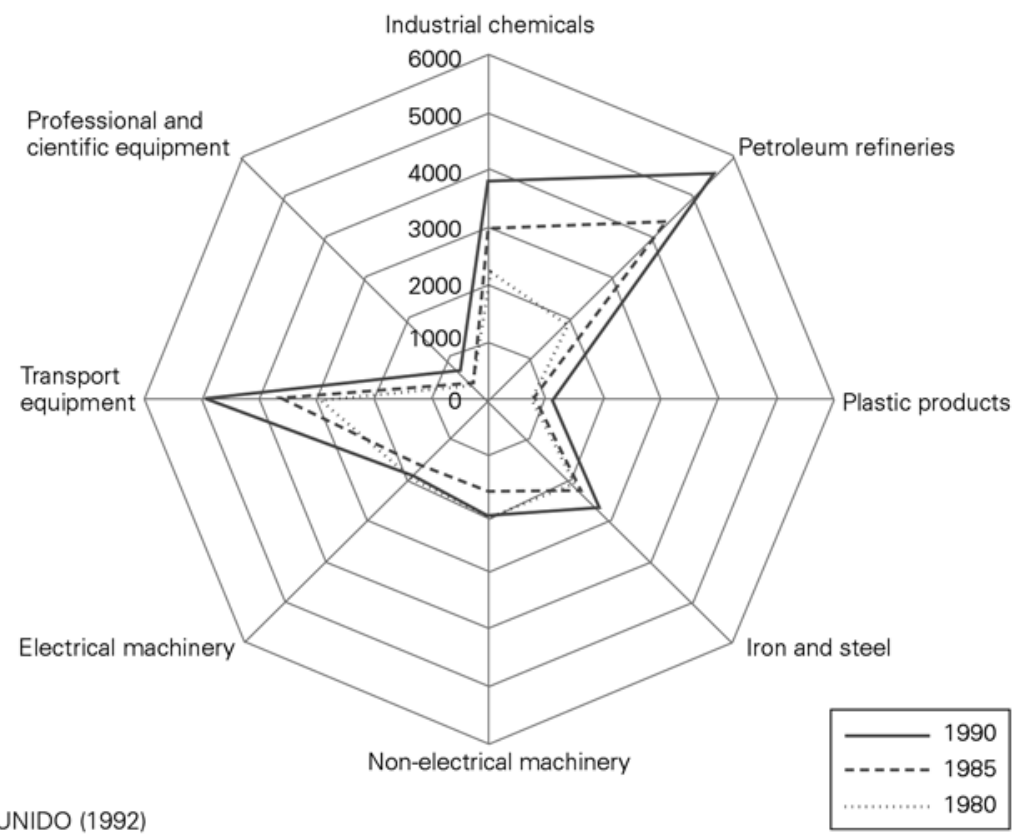


Figure 5: Korea: Export structure by selected sectors (percentage)

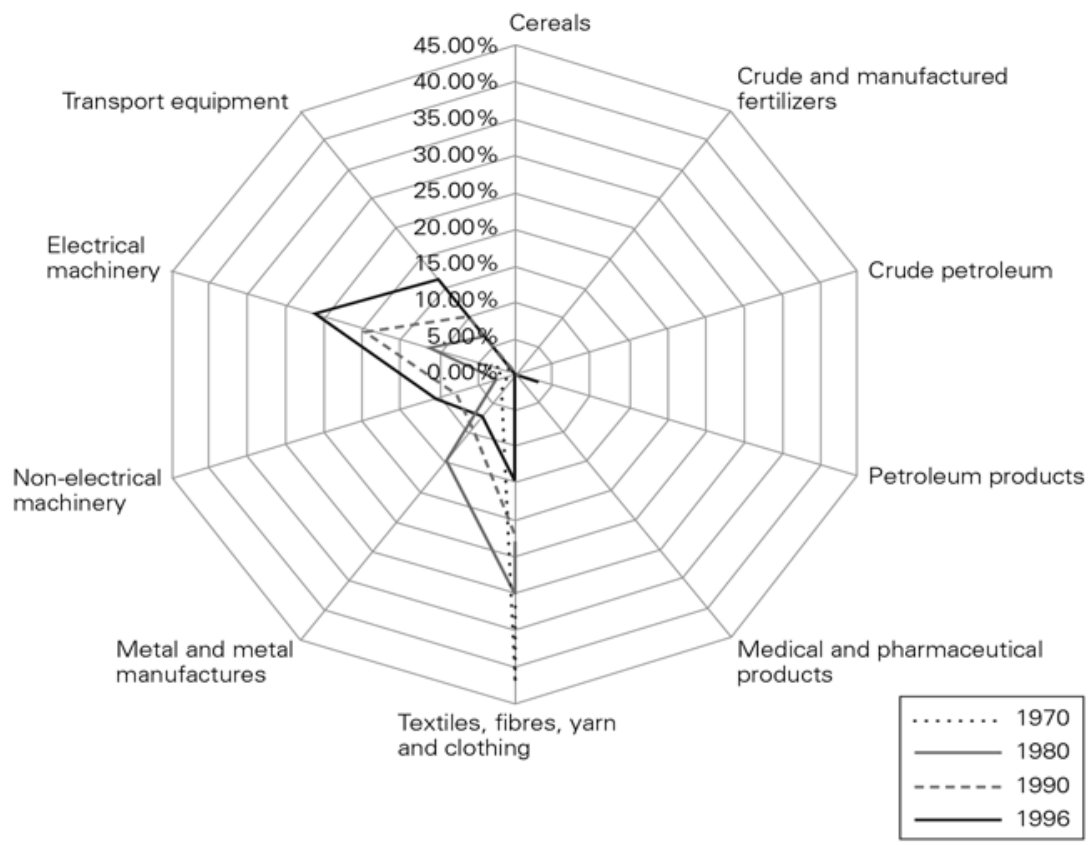

Figure 6: Taiwan: Export structure by selected sectors (percentage)

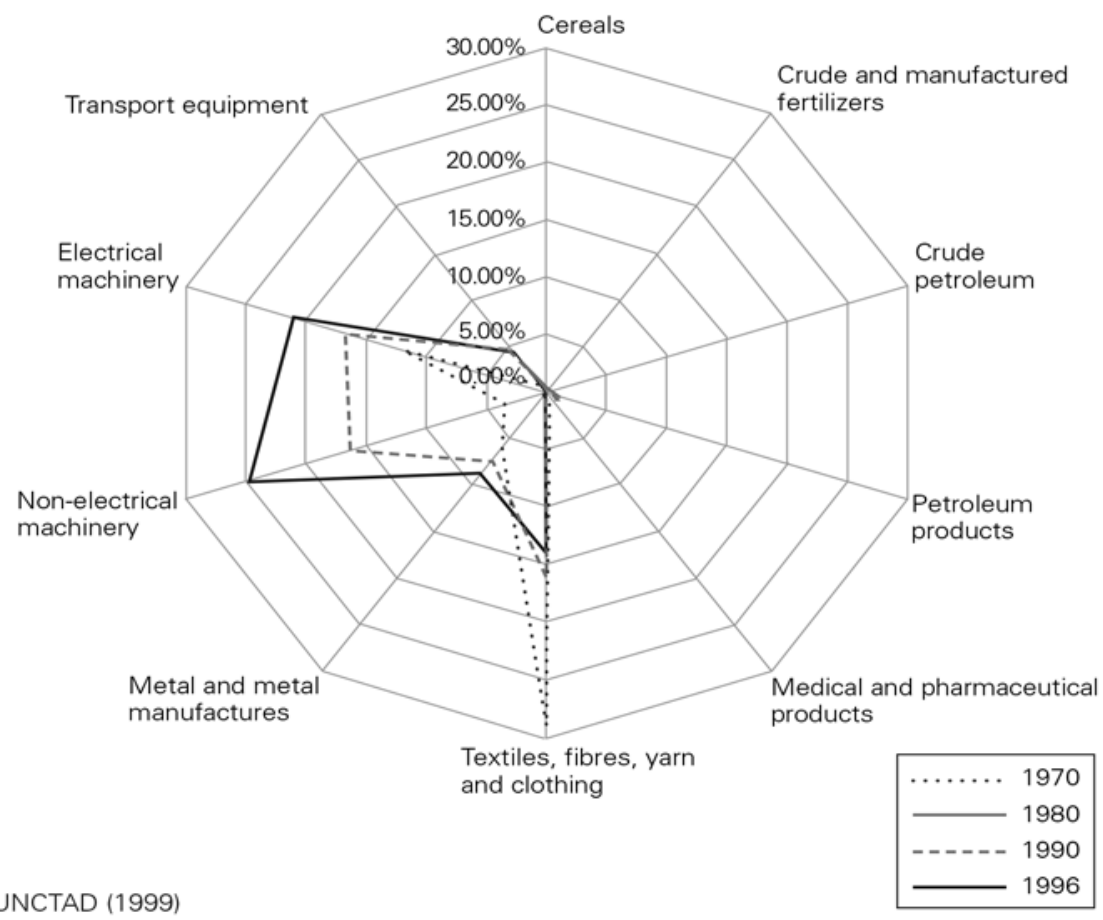


Figure 7: Hong Kong: Export structure by selected sectors (percentage)

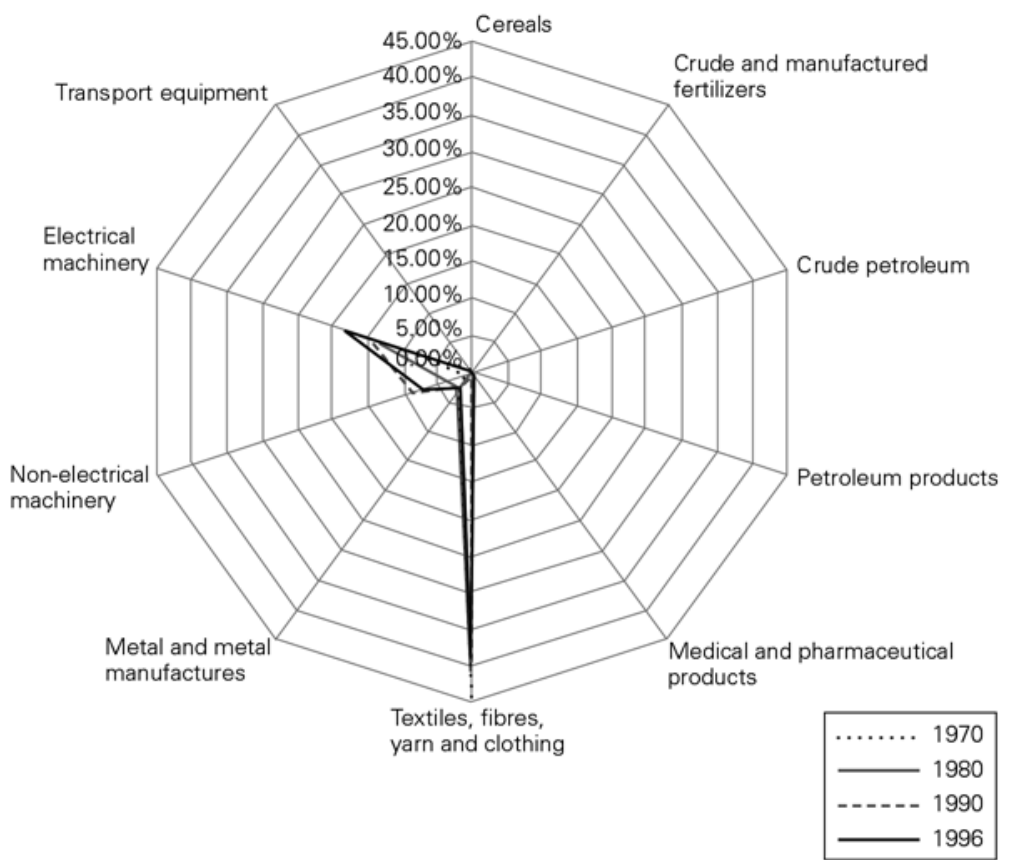

Figure 8: Argentina: Export structure by selected sectors (percentage)

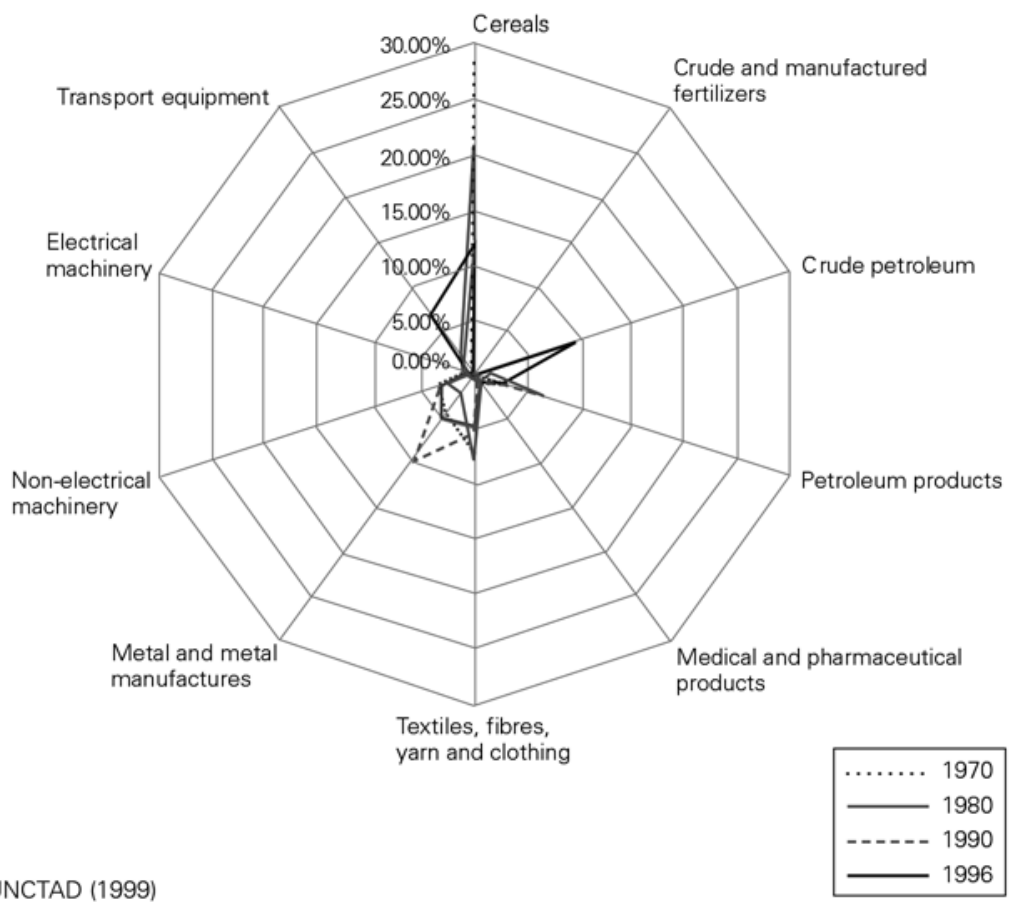


Figure 9: Brazil: Export structure by selected sectors (percentage)

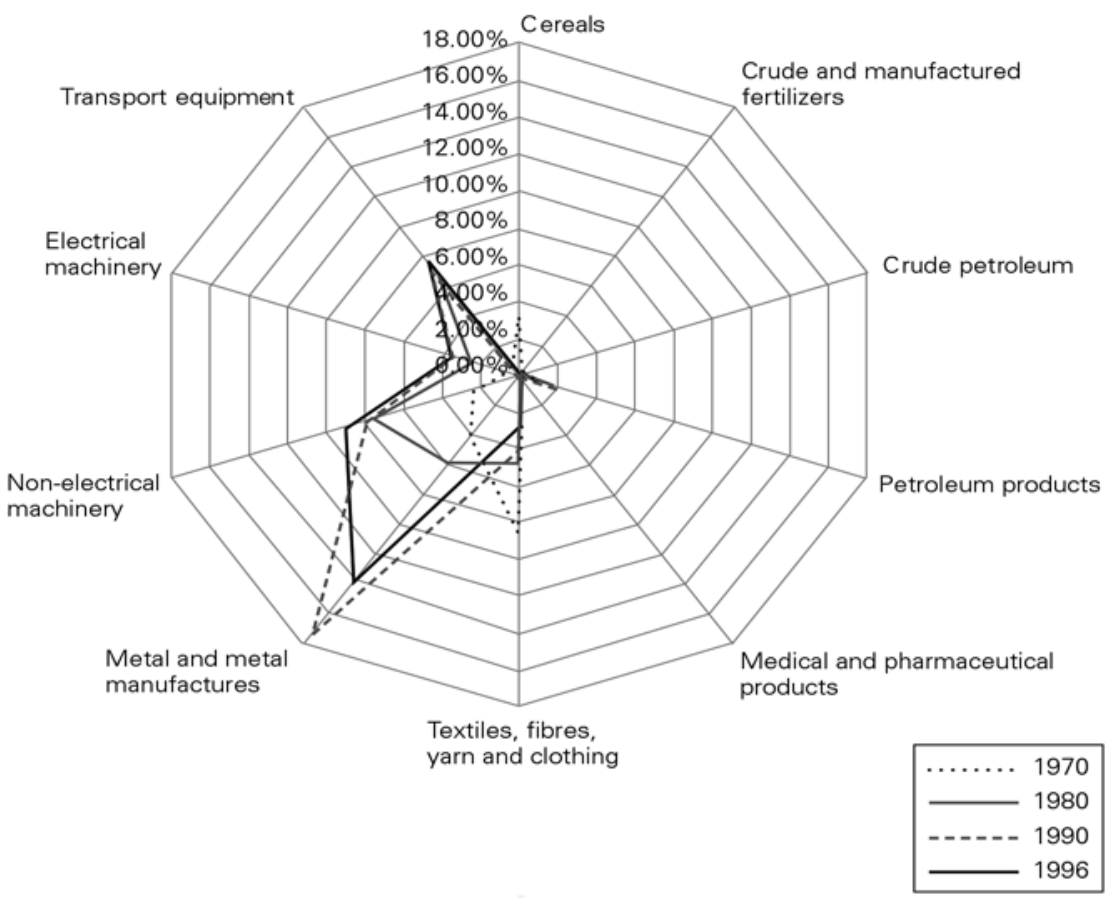

Figure 10: Mexico: Export structure by selected sectors (percentage)

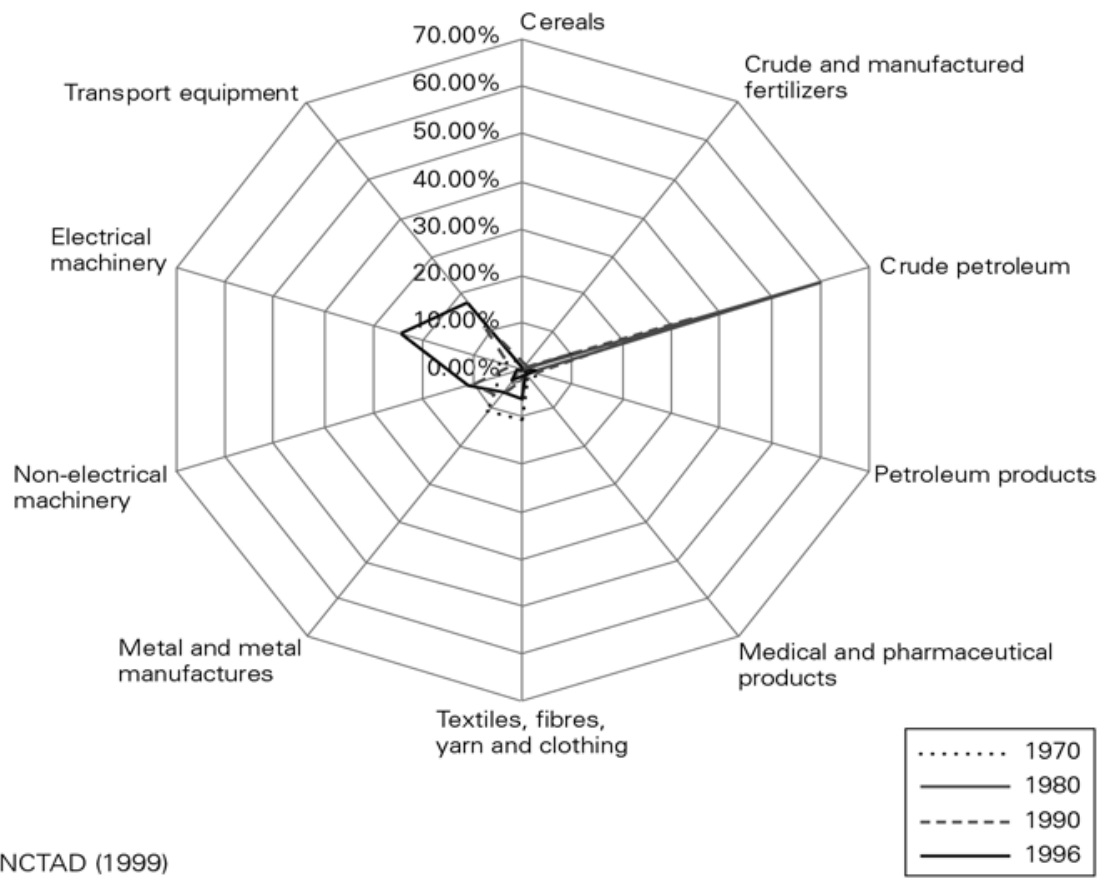


the changes in industrial structure between 1980, 1985 and 1990 in Korea, Argentina, Brazil and Mexico. Each figure portrays change in level of output (in 1980 US\$ millions) across eight industrial sectors. Over the period considered, Korea deepened considerably its specialisation in electrical machinery (Figure 1). To a lesser extent, it specialised in transport equipment and non-electrical machinery sectors and lesser still in resourceintensive sectors such as iron and steel and industrial chemicals.

In contrast, Figure 2 reveals that Argentina continued its previous trend, specialising strongly in a resource-intensive sector, petroleum refineries. It also specialises in industrial chemicals and iron and steel. The exception to specialisation in resource intensive sectors is the specialisation in transport equipment, given that the auto industry has been the object of special regimes since its development in the post-war period (which favours large transnational corporations and their linked foreign suppliers) (Miozzo, 2000). Figure 3 shows that Brazil has a less pointed specialisation in resource-intensive sectors than Argentina, combining a specialisation in non-electrical machinery and electrical machinery and transport with resource-based sectors such as iron and steel, petroleum refineries and industrial chemicals. Figure 4 shows Mexico's pointed specialisation in resource intensive sectors such as petroleum refineries and industrial chemicals, on the one hand, and in transport equipment and non-electrical and electrical machinery on the other. Much of these developments in transport equipment, garments, consumer electronics and semiconductors are related to the foreign-assembly factories ('maquiladoras') in the Mexican-US border.

Figures 5 to 10 show the changes in export structure for all six countries in selected industrial sectors from 1970 to 1980 to 1990 and to 1996. Korea has retreated very strongly from textiles and, to a lesser extent, from metals. Instead, it has progressed strongly into exports of electrical machinery and, to a lesser extent, into transport equipment (Figure 5). Similarly, Figure 6 reveals that Taiwan has also retreated from textiles and has progressed into non-electrical machinery and transport equipment. Figure 7 shows that Hong Kong retreated more slowly from textiles and progressed slowly into electrical machinery.

In contrast, Figure 8 reveals that Argentina has retreated from cereals and, to a lesser extent, textiles and has progressed into crude petroleum. The increase in exports in the only non-resource-based sectors such as transport equipment, as argued above, responds to a special incentive. Figure 9 shows that Brazil has retreated from textiles and metals and progressed into non-electrical machinery and transport equipment. Figure 10 shows that Mexico has retreated from crude petroleum and has progressed into electrical machinery and transport equipment.

Table 1 shows that the world share of machine tool consumption (indicative of machinery production and use) in Korea and Taiwan are well above that of Brazil, Mexico and Argentina. Allowing for differences in population the disparities are enormous. 
Table 1: Latin American and East Asian machine-tool consumption

\begin{tabular}{lccc}
$\begin{array}{c}\text { Country by } \\
\text { world share }\end{array}$ & $\begin{array}{c}\text { Consumption } \\
\text { (million dollars) }\end{array}$ & $\begin{array}{c}\text { World } \\
\text { share }\end{array}$ & $\begin{array}{c}\text { Machine-tool consumption } \\
\text { (million dollars) / population (millions) }\end{array}$ \\
\hline Korea & 1581.4 & 3.85 & 39.09 \\
Taiwan & 615.8 & 1.5 & 32.50 \\
Brazil & 356 & 0.87 & 2.94 \\
Mexico & 255 & 0.62 & 3.14 \\
Argentina & 82.8 & 0.2 & 2.54 \\
Hong Kong & 12.2 & 0.03 & 2.26 \\
\hline
\end{tabular}

Source: UNIDO (1992)

While the figures above reflect a growing specialisation in production and trade in machinery sectors in East Asia and a declining specialisation in these sectors in Latin America, the next section examines the institutional differences that explain these processes of structural change.

\section{INSTITUTIONS OF INDUSTRIALISATION IN EAST ASIA AND LATIN AMERICA}

The divergence between East Asia and Latin America has grown over the last forty years. At least since the early 1960s, Taiwan and Korea, following Hong Kong, have progressively integrated into the international production system by targeting sequentially industrial sectors with higher levels of value added, by increasing the skill and technology intensity of manufacturing exports and by reducing their natural resource and unskilled labour-intensive industries. Latin American countries, instead, have experienced a decline in production in the prototypical import substitution industries (such as metal manufactures and machinery sectors and consumer durable goods). These countries have undergone a restructuring towards the production of industrial inputs that exploit natural resources and towards a growing assembly of imported components. This is accompanied by a process of international integration that reduces the contribution of domestic subcontractors and suppliers to scale intensive operations (Cimoli et al., 1998; Miozzo, 2000). As argued in section 1, the increasing dependence on imported capital goods and the disappearance of machinery sectors may conspire against the development of incremental learning and the development of technological capability.

This section argues that the main institutional arrangements in place in East Asia and Latin America explain these divergences. In particular, the differences between the two regions in the strategy and structure of leading firms, the role of the government, the development of small and medium-sized firms and the presence 
and operation of foreign-owned firms may explain the respective success and failure in sectoral specialisation in machinery.

\section{Strategy and structure of leading firms}

A major contributory factor to these divergences has been differences in the organisation of leading business firms. On the face of it, there are striking similarities in structures between the two regions. In both East Asia and Latin America, an important agent of industrialisation in the post-war period has been closely-held diversified business groups owned and managed by a tight circle of family members and friends.

In contrast to the multidivisional firms from advanced countries (Chandler, 1977), the basis of diversification of which was their proprietary core technology, which they exploited in technologically related industries, industrial groups in late industrialising countries (Japanese zaibatsu, Korean chaebols and Latin American grupos) have diversified into technologically unrelated industries. This has been facilitated by the increased codification of technology and opportunities to buy foreign technology from advanced countries (Amsden, 1989). Nevertheless, while in both East Asia and Latin America the groups have received support from the state, only in East Asia have they been 'disciplined' when they have not met monitorable performance standards (Amsden, 1989).

For example, in Korea, the banking system was state run until 1981/83 when banks were privatised; and even then they remained effectively under state control (Etzkowitz and Brisolla, 1999). They lent long term, at low interest rates and in large amounts to selected chaebols for approved investments. Chaebols also depended on the state for export and import licences (Amsden, 1989; Castells, 1992). The availability of large-scale, long-term state finance in East Asia meant that the transition between sectors and products could be rather abrupt and not depend heavily on the profitability and efficiency of existing investments. It was therefore possible for the Korean chaebols to target scale-intensive, mid-technology areas - historically, electrical machinery, basic chemicals, automobiles, consumer electronics and commodity semiconductors more recently. In these areas, technology, although expensive, is available from international suppliers, there are fewer technological barriers than in high-technology areas and is not vulnerable from lower wage competitors (Amsden, 1989).

Industrial groups in Latin America may seem very similar in character to the Korean chaebols. Like the chaebols, they are family-controlled and highly diversified by sector. Like the chaebols, they have privileged access to capital, and advantageous connections with government. Appearances, however, are deceptive. Chaebols have secured captive loan funds that protect them from restrictive monetary policies and safeguard long-term investment programmes. But the crucial objective is to carry out investment programmes and by doing so get ahead of rivals (Mortimore, 1993; Ruiz, 1997; Amsden, 1989). In Latin America, on the other hand, the relation between industrial groups and banks is a way of maximising financial 
returns on idle monetary resources or working capital. They are not aimed at forming structures to back long-term investments. Periods of recession, fluctuating and rising interest rates and the increasingly short-term nature of available finance have worsened the above (Griffith-Jones, 1998).

Indeed, differences are evident when in the late 1980s and early 1990s the traditional mechanisms of industrial policy and financial regulation were dismantled in Korea. The response of Korean industrial groups was utterly unlike what would have been expected in Latin America. The chaebols responded to the new situation of freedom and uncertainty by overborrowing massively from domestic and foreign banks in their competitive struggle against one another - running risks of bankruptcy that became apparent in the 1997/99 crisis (Chang et al., 1998).

Indeed, these differences explain the divergent specialisation of East Asia and Latin America as illustrated in Table 2. As we can see in Table 2, while in Korea, the most important sector in which the economic activities of the largest groups has been growing in the last decades is electronics, in Brazil it is in iron and steel and in Mexico, glass. While in Korea large business groups have invested in internationally competitive sectors, business groups in Latin America have receded into 'nontradable' sectors or sectors where there are rents based on the exploitation of natural resources, bureaucratic lobbying and opportunistic behaviour.

In this sense, Brazil and Argentina offer good examples of how these business groups restructured their operations retreating from the internationally dynamic machinery sectors. In Brazil, the 1980s and 1990s has been characterised by instability and uncertainty and has led to a restructuring of the largest domestic economic groups. These large groups (such as Weg, Bunge y Born, Suzano, Vicunha and ABCAlgar) include firms in the mining, real estate and reforestation sectors, as well as shares in other industrial corporations. Large firms had incentives to keep high liquidity levels and put their surplus into the capital market. The groups restricted their investment to areas of strategic importance, leading to the buying out of competitors and forward or backward integration (such as the cases of Vicunha, Gerdau, Belgo-Mineira and Votorantim) and to increase their exports (Ruiz, 1997). Their restructuring, however, neglected those areas of expansion related to new technologies, especially the electronics and electromechanical industries (an exception to this is the large state share in the telecommunications sector). Most now concentrate on sluggish activities such as foodstuffs and beverages, ferrous metals, textiles and clothing, and non-ferrous metals. Within foodstuffs, firms shifted their production to industries such as soy beans and soy products, meat and poultry and concentrated juices, which make intensive use of natural resources and involve little industrial processing (Ruiz, 1997). Only a few groups (Cofap, Weg, Dedini, Machline) maintained a presence in dynamic technology-intensive activities, and specifically in machinery sectors (see Table 2). 
Table 2: East Asia and Latin America: sales by largest economic groups and main activity, 1980-1993 (millions of \$US)

\begin{tabular}{|c|c|c|c|}
\hline Main Activity & Name of Groups & Sales 1980 & Sales 1993 \\
\hline \multicolumn{4}{|l|}{ South Korea } \\
\hline Electronics & Samsung, Daewoo, Goldstar & 3798 & 87604 \\
\hline Petrochemicals & Sunkyong, Ssangyong, Honam Oil & 3157 & 34658 \\
\hline Transport equipment & Hyundai & 5540 & 9204 \\
\hline Textiles & Hyosung & 1950 & 6332 \\
\hline \multicolumn{4}{|l|}{ Brazil } \\
\hline Iron and steel & Votorantim, Gerdau, Belgo-Minera, Villares & 2005 & 5575 \\
\hline Agricultural activities & Sadia, Perdigao, Itamarati* , ABC-Algar & 699 & 3008 \\
\hline Textiles & Hering, Vicunha, Alpargatas & 1112 & 2947 \\
\hline Petrochemicals & Ipiranga, Ultra, & 2121 & 2597 \\
\hline Beverages & Antartica, Brahma* & 802 & 1455 \\
\hline Paper and paperboard & Klabin, Suzano & 516 & 1188 \\
\hline Electronics & Machline & 246 & 1040 \\
\hline Transport equipment & Cofap, Metal Leve, & 262 & 887 \\
\hline Mining activities & Caemi, Paranapanema, & 795 & 774 \\
\hline Mechanical engineering & Dedini & 185 & 338 \\
\hline Electromechanical & Weg & 65 & 181 \\
\hline \multicolumn{4}{|l|}{ Mexico } \\
\hline Glass & Vitro & & $3309 *$ \\
\hline Telecommunications & Carso & & $2554^{*}$ \\
\hline Iron and steel & Alfa & & $2493^{*}$ \\
\hline Cement & Cemex & & $2213^{*}$ \\
\hline Beverages & Visa & & $2100^{*}$ \\
\hline Mining & Minera Mexico, Penoles & & $1669 *$ \\
\hline Transport equipment & Desc & & $1654^{*}$ \\
\hline Tobacco & La Moderna & & $921^{*}$ \\
\hline
\end{tabular}

Source: Ruiz (1997); Garrido (1994). * figures for 1992.

In Argentina, the liberalisation of the mid-1970s brought an advantage to firms that could shift resources rapidly, leading to the expansion of domestic groups and diversified foreign corporations. Although some of these groups dated from the beginning of Argentine industrialisation, the expansion in the economic influence of these twenty five large closely held, vertically and horizontally-integrated groups is the most marked characteristic of the 1980s and 1990s. Examples of these are Perez Companc (in fish, mining, oil, food, motors, construction, finance) and Garovaglio y Zorraquin (in mining, agro, petrochemicals, food, textile, metal and finance). 
In the 1980s and 1990s these large groups (especially Perez Companc, Techint, Citicorp and Astra) expanded through the purchase of state firms, through preferential treatment in utilities such as electricity or natural gas and through the ease of transfer of resources and cross-subsidies between firms and vertical and horizontal integration. This resulted in an increase in economic concentration with $1 / 3$ of the top firms accounting for $2 / 3$ of aggregate sales. Privatisation benefited these groups, not only through the transfer of assets but also of the power to determine relative prices and public service tariffs in oligopolistic markets.

The structure of industry has changed dramatically in the 1990s, with 97 new firms among the top 200 firms (Azpiazu, 1997). This can be explained by the disappearance of privatised state firms, the rise of new privatised public service firms, and a loss of the position of manufacturing firms and a rise in firms engaged in the trade of imported goods and in services production. Firms in trade (supermarket chains, primary product exporters) have increased their participation from $5.6 \%$ to $15.9 \%$ in the top 2000 firms in the 1990 s (Azpiazu, 1997). Input producers recovered their economic position in the mid 1990s (Aluar, Ipako, PASA, Loma Negra, Indupa, Petroquimica Bahia Blanca, Siderca, Polisur, Petroken). A growth in tradable but naturally protected goods, such as cement, and a notable growth in exports of intermediate inputs, such as petrochemicals and steel, explain most manufacturing production (Azpiazu et al., 1986; Azpiazu, 1997).

Thus, diversified business groups have operated in a very different way in East Asia and Latin America. In East Asia, chaebols diversified because they have the resources to compete with one another across a range of medium-technology industries favoured by government for expansion. The diversification of Latin American groups, instead, is because of the limited alternatives for diversifying risk in a portfolio of securities (therefore firms diversify in real assets). In East Asia, the support to business groups was largely targeted to key areas of mechanical, electrical and electronic machinery suitable to large scale and 'patient' finance such as the state could provide. In Latin America, instead, state support and liberalisation led to a retraction from these sectors and an expansion of 'non-tradable' and intermediate industries.

\section{Industrial promotion by the state}

As implied in the previous sub-section, the second major contributory factor to these divergences has been the nature of state promotion of industrial activity.

While in both East Asia and Latin America, groups have received state support, only in the former did they have to meet monitorable performance standards or otherwise experience a withdrawal of this support (Amsden, 1989) while there has been no such performance standards and 'discipline' of Latin American business groups.

Korea and Taiwan offer good illustrations of such 'discipline' exerted over business groups. Licences to expand the scale of production of firms in Korea were granted only as long as firms could prove satisfactory performance in exports, 
$R \& D$ and in the introduction of new products (Amsden, 1989). Taiwan has relied more on fiscal incentives, administered selectively to promote industrial priorities. Subsidies to export, however, were also tied to targets such as R\&D spending and personnel training (Wade, 1990).

In Latin America, while the state has been the main instrument for the coordination of investment, no enforceable standards where exerted on the leading firms receiving state support. In Argentina, the state assumed an important role between the 1950s and the mid 1970s, in promoting import substitution industrialisation (Azpiazu et al., 1986). This was in the form of subsidies to private domestic investment (especially through the Industrial Bank created in 1944), the promotion of foreign investment (especially from the US), the creation of state enterprises and as arbiter of social struggles over the distribution of income. In Brazil, tax breaks, credits, investment licenses, import facilities and export promotion were important elements of industrial policy. The state budget (through the inflationary tax and government bonds) and foreign borrowing in the 1970s and 1980s funded industrialisation. In all countries, the government allowed large domestic firms to appropriate important rents, through high levels of protection and subsidies, but imposed no 'sticks'. In Brazil, the few exceptions to this rule were the procurement policy of Petrobras, the state oil company, which subjected suppliers to quality controls and the BEFIEX export subsidy based on quantitative export obligations (Meyer-Stamer, 1997). As

such, government policies did not succeed in promoting entry into activities with 'difficult' technologies and encourage the undertaking of complex, new technological functions as in East Asia (Lall and Teubal, 1998). In particular, this operated in detriment of the development of an internationally competitive machinery and capital goods sectors at the time when industrialised countries where experiencing a transition from electromechanical to electronic production.

As will be argued in the last sub-section, another contributory factor to these divergences is the attitude of the government to relations with foreign-owned firms. In East Asia the state encouraged autonomous relationships with foreign multinationals, which could provide technology and market access - in Latin America it encouraged the entry of the foreign multinationals themselves. Machinery and transport equipment sectors which are institutionally complex, requiring careful management of relationships with other firms and with workers, and attention to technological detail, have been left to the weak and undercapitalised small and medium enterprises, and to multinationals.

\section{Development and support of small and medium-sized firms}

A third contributory factor has been the notably difference in development and support received by medium and small-sized firms in East Asia and Latin America. East Asian countries have managed to build a dense network of small businesses which ensures their survival and inter-firm cooperation needed in the machinery sectors. There have been no comparable developments in Latin America.

In Hong Kong, for example, more than $90 \%$ of manufacturing firms employ 
less than 50 workers (Castells, 1992). The government in Hong Kong was instrumental in the development of the industrial structure in an indirect way through the early distribution of export quotas under the MultiFibre Agreement, the development of information and training centres in the 1960s and the creation of such institutions as the Hong Kong Credit insurance corporations. Besides offering support and information on world markets, ways of upgrading production practices and machinery, the government ensured a climate of industrial stability and subsidised collective consumption to support the growth of small- and medium-sized firms. In particular, a public housing program provided housing for $45 \%$ of the population, representing a $50 \%$ subsidy for each household (Castells, 1992).

Like Japan, during the 1950s Korea and Taiwan carried out a land reform programme that gave the rural poor in Korea and Taiwan a subsistence base from which they could afford to sell their surplus labour at very low wages. This was a basis on which to build a dense network of (mostly) small businesses, family-owned and controlled, providing rather basic consumer and industrial goods. The basic nature of the consumer goods was enough to satisfy the market at this point, since, largely due to the land reform, these countries had quite exceptionally low inequality of incomes. The Taiwanese state confined its involvement in the economy to the areas which the country clearly needed to be in (like steelmaking) and were clearly too large scale for family capitalism to handle. There is now, accordingly, a number of large state-owned firms that dominate the capital-intensive sectors. A multitude of smaller enterprises was set up with family and co-operative savings and supported by bank credit, employing family members who also worked on the land (the land reform creating a population of small farmers). There was a maximum degree of specialisation and cooperation among companies, linked by kinship and friendship and locality (Whitley, 1992). From this base, a flexible decentralised network of small and medium-sized firms focussing on the export trade in consumer goods has developed.

This picture contrasts heavily with that of Latin America. In Argentina, in the late nineteenth and early twentieth centuries, it is also immigrants and large foreign firms turning from exporters to manufacturers who led in the development of manufacturing industry in Latin America. Unfortunately, immigrants (of Lebanese, Jewish, Italian and German origin, in the case of Argentina) never had anywhere near the dominant social or political influence achieved by the Chinese in East Asia. This can be explained by the kind of industries most characteristic of the first phase of import substituting-industrialisation (consumer goods - not a strong base) and by the continued political influence of land-owning interest and the dependence on exports of primary products for the foreign exchange required for imports (Hirschman, 1971).

Immigrants had an important role in setting up industrial firms and this was as true for machinery and transport equipment sectors as for any other sector $(90 \%$ of industrial enterprises in Buenos Aires were owned by immigrants in 1895 and over $60 \%$ in 1935). However, contrary to the USA, the naturalisation and political participation of immigrants was low (Cornbilt, 1967), explaining the relative lack 
of political influence and prestige of industry in the early post-war period. There have been no state initiatives to foster networks of firms with (for example) local and regional credit institutions and trade associations.

Deregulation and liberalisation of the economy in Latin America increased economic concentration, with the contraction of domestic small and medium-sized firms against the relative success of a few capital-intensive sectors and large groups in these sectors. For example, Argentina was producing in this period half the number of automobiles, machine-tools and tractors than it was ten years before. Medium and small-sized firms fell by $10 \%$ between 1974 and 1985 . These firms, which were suppliers and producers of components for the machinery and transport equipment were heavily affected by the deterioration of general economic infrastructure in the 1980s and by the entry of foreign suppliers in the 1990s.

Brazil may be considered an exception in that it has important industry clusters which include smaller firms (women's shoes in Sinos valley in Rio Grande do Sul, men's and children's shoes in the interior of the state of Sao Paulo, ceramic tiles in the south of Santa Catarina, automotive and capital goods industry around the city of Sao Paulo and consumer electronics industry in Manaus and petrochemical industry in Cubatao, Camacari and Triunfo). Nevertheless, clientelism and the lack of defined local and national responsibility threaten regional initiatives that could lead to a support of inter-firm linkages and development of domestic suppliers over industrial policy decisions (Meyer-Stamer, 1997).

The development of a decentralised network of small and medium-sized firms in East Asia supports their specialisation in consumer exports and as suppliers of components in machinery sectors. The lack of support and uncertainty in Latin America has led to a contraction of small and medium-sized firms since the mid1970s. Since the production of machinery requires the assembly of components often produced by small and medium-sized suppliers, the machinery sector in Latin America has been severely endangered by the contraction of the small and medium-sized firms sector.

\section{Presence and relations with foreign-owned firms}

Another major contributory factor to these differences is the role of foreign direct investment in East Asia and Latin America and the nature of the relations between foreign and domestic firms. While these relations have led to the upgrading of technological capability in East Asian domestic firms, in Latin America these relations have had the opposite effect, leading to a reduction in the contribution and quality of domestic subcontractors and suppliers.

The presence of foreign-owned firms has been and remains stronger in Latin America than in Taiwan or Korea (out of the top 10 firms, for example, 4 in Mexico were foreign owned and 3 in Brazil yet none in Taiwan or Korea in the early 1990s) (Amsden and Hikino, 1994). This is not to say that multinational corporations have not played an important role in the favourable economic performance of East Asian countries. In East Asia, business groups have forged links 
with firms in sectors that generate new technologies (such as microelectronics and electrical equipment) and use new technologies (such as motor vehicles, chemicals and telecommunications). While domestic firms have been the agents of industrialisation, they have done so largely as suppliers to Japanese firms. Japanese minority capital or non-equity participation in domestic firms has ensured technological upgrading. These selected foreign investments created initially low cost sourcing centres and subcontracting with export-orientation.

The chaebols, and the Korean state, have managed their relationships with foreign industrial capital very carefully. The chaebols refused equity participation of foreign enterprises until the 1970s but even then with strong restrictions. In their policy of largely independent development they took full advantage of the increased codification of technology and its international availability. In the 1980s, Korea formed partnerships with Japanese industry and used original equipment manufacturer (OEM) agreements to supply electronic products and equipment to Japanese firms, making rapid technological advances possible (Etzkowitz and Brisolla, 1999).

Taiwanese firms initially concentrated on production, depending on US and Japanese partners for technology and marketing, including brand names. They became subcontractors of American multinationals or medium-sized Japanese firms, and suppliers of international commercial networks (through Japanese trading companies and American department stores) (Castells, 1992). As in Korea, dependence on foreign providers of technology has been carefully managed so that it would not be permanent. Despite its relatively small magnitude, in qualitative terms, foreign direct investment has been important, as it has been in Korea, to develop certain key industries and has been used in conjunction with a national technology system (Singh and Zammit, 1998).

In Latin America, instead, during the post-war period, US multinationals dominated the more technologically dynamic sectors such as machinery and chemicals. This was in the form of subsidiaries or majority-owned affiliates. The limited efficiency of their operations acted as an obstacle against them serving as a competitive stimulus for domestic firms, especially in terms of exports (Mortimore, 1993). More recently, Latin American countries are undergoing a process of international integration that reduces the contribution of domestic subcontractors and suppliers to scale intensive operations led by large business groups and multinational firms (Cimoli et al., 1998; Miozzo, 2000).

In East Asia, therefore, foreign direct investment was managed to ensure technological and organisational improvements. In Latin America, instead, the private business interests of transnational corporations have superseded national interests - they make limited investment in R\&D and there is a lack of attention to linkages with local suppliers. Increasing dependence on imported components has led to a neglect of previous domestic experience in machinery production and accumulated levels of engineering skills and know-how. 


\section{CONCLUSION}

The divergence since the 1970s may be explained in terms of differences in prevailing institutional arrangements. East Asian countries have been successful at specialising in machinery and transport equipment sectors, which have become the fastest growing category in world exports. In Latin America, instead, liberalisation and privatisation have accelerated the process of structural change, reinforcing a pattern of specialisation towards natural comparative advantages. Domestic groups and a small number of foreign firms have established modern plants producing capital intensive, intermediate, resource-intensive goods with up-to-date process technology, exporting in competitive markets, where Latin American countries are pricetakers. The production of these goods, such as iron and steel, petrochemicals, vegetable oils and paper, has grown at the expense of final labour intensive goods and technology-intensive goods. An exception has been the auto industry, the object of ad hoc industrial policy of a different nature in Brazil and Argentina, on the one hand, and Mexico. Another exception is the Mexican 'maquila' - an enclave of foreign firms producing computer equipment, televisions, etc. - protecting them from liberalisation and the generalised deregulation of economy.

An explanation for this divergence can be found in the different institutional arrangements in East Asia and Latin America. The strategy and structure of leading firms, the nature of industrial promotion by the state, the development and support of small and medium-sized firms and the presence and relations with foreign-owned firms account for differences in sectoral specialisation.

The relevance of this specialisation for new developments in customised, projectbased industries (such as aerospace and nuclear power equipment) and for sciencebased industries such as biotechnology may be limited. In the first case, competitive advantage seldom rests on volume production costs and incremental process improvements. In biotechnology, the novelty and science-based nature of the knowledge base implies that industrial applications rely on the formation of strong scientific capabilities as a necessary prerequisite for the accumulation of technological capabilities (Orsenigo, 1993). However, machinery sectors have a demonstration effect on most other sectors. Hobday has pointed out the relevance of a specialisation in machinery sectors for the developments of electronics: "Like the newly industrialised countries, other developing countries should take very seriously the lowtechnology side of so-called high-technology industries. Only by developing capabilities in fields such as plastics, molding, machinery, assembly and electromechanical interfacing, did East Asia emerge as the leading export region for electronics. This, in turn, suggests that educational policies should ensure an adequate supply of technicians and engineers in low as well as high-technology fields." (Hobday, 1995b, p. 1188).

This paper seeks to contribute to a comparative research agenda in LDCs that may provide scope to learn about the institutional conditions that support the development of domestic technological capability. In the policy front, there has been a neglect of matters of institutional arrangements and their relation to the accumu- 
lation of institutional resources to generate and manage technological and organisational changes. In particular, there is a need to ensure the development of structures to finance long-term investment in industry, broad skills and linkages along the production process. Attention to these matters will have an important impact on growth and equality. In the absence of manufacturing capability and skills in the production of machinery, a number of LDCs will be at a disadvantage in the accumulation of skills and incremental knowledge that are necessary for the growth of new technology-intensive sectors.

\section{REFERENCES}

AMSDEN, A. (1989) Asia's Next Giant: South Korea and Late Industrialisation. Oxford University Press: New York.

AMSDEN, A. and T. HIKINO (1994), 'Project execution capability, organisational know-how and conglomerate corporate growth in late industrialisation', Industrial and Corporate Change, 3, 1: 111147.

AZPIAZU, D. (1997), 'El nuevo perfil de la elite empresaria', Realidad Economica, 145: 7-43.

AZPIAZU, D., E. BASUALDO and M. KHAVISSE (1986) El nuevo poder economico en la Argentina. Legasa: Buenos Aires.

BHALLA, A. S. (1979) Towards Global Action for Appropriate Technology. Pergamon: Oxford.

CASTELLS, M. (1992), 'Four Asian tigers with a dragon head: a comparative analysis of the state, economy and society in the Asian Pacific Rim', in R. P. Appelbaum and J. Henderson (eds.), States and Development in the Asian Pacific Rim, Sage: London: 33-70.

CHANDLER, A. (1977) The Visible Hand: The Managerial Revolution in American Business. Harvard University Press: Cambridge, MA.

CHANG, H. H. PARK and C. YOO (1998), 'Interpreting the Korean crisis: financial liberalisation, industrial policy and corporate governance', Cambridge Journal of Economics, 22, 6: 735-46.

CIMOLI, M, F. CINGANO and M. DELLA GIUSTA (1998), 'Historical modes of industrial development, technological capabilities and competitiveness in Mexico', mimeo.

CORNBILT, O. (1967), 'Inmigrantes y empresarios en la politica Argentina', Desarrollo Economico, 6, 24: 641-91.

ETZKOWITZ, H. and S. BRISOLLA (1999), 'Failure and success: the fate of industrial policy in Latin America and South East Asia', Research Policy, 28: 337-50.

EVANS, P. and P. TIGRE (1993), 'Paths to participation in "hi-tech" industry: a comparative analysis of computers in Brazil and Korea', in D. Chudnovsky (ed.) Transnational Corporation and Industrialisation, United National Library on Tranational Corporations, Routledge: London: 283-308. FRANSMAN, M and K. KING (1984) Technological Capability in the Third World. Macmillan Press: London.

GARRIDO, C. (1994), 'National private groups in Mexico, 1987-1993', CEPAL Review, 53: 159-176. GRIFFITH-Jones, S. (1998) Global Capital Flows: Should they be Regulated? Macmillan: London.

HAYAMI, Y. and V. RUTTAN (1971) Agricultural Development: An International Perspective. Johns Hopkins University Press: Baltimore.

HIRSCHMAN, A. (1971), 'The political economy of import-substituting industrialisation in Latin

America', in A. Hirschman (ed.), A Bias for Hope: Essays on Development in Latin America, Yale University Press: New Haven: 85-123.

HIRCHSMAN, A. (1958) The Strategy of Economic Development. Yale University Press: New Haven.

HOBDAY, M. (1995a) Innovation in East Asia: The Challenge to Japan. Edward Elgar: Cheltenham, UK. 
HOBDAY, M. (1995b), 'East Asian Latecomer Firms: Learning the technology of Electronics', World Development, 23, 7: 1171-1193.

HOLLINGSWORTH, J. R., P. SCHMITTER and W. STREECK (1994) Governing Capitalist Economies: Performance and Control of Economic Sectors, Oxford University Press: Oxford.

LALL, S. (1987) Learning to Industrialise. Macmillan: London.

LALL, S. and M. TEUBAL (1998), 'Market-stimulating' technology policies in developing countries: a framework with examples from East Asia', World Development, 26, 8: 1369-1385.

MEYER-STAMER, J. (1997), 'New patterns of governance for industrial change: Perspectives for Brazil', The Journal of Development Studies, 33, 3: 364-391.

MIOZZO, M. (2000), 'Transnational corporations, industrial policy and the 'war of incentives': the case of the Argentine Automobile Industry', Development and Change, 31,3: 651-680.

MORTIMORE, M. (1993), 'Flying geese or sitting ducks? Transnationals and industry in developing countries', CEPAL Review, 51: 15-34.

SINGH, A. and A. ZAMMIT (1998), 'Foreign direct investment: towards co-operative institutional arrangements between the North and the South', in J. Michie and J. Grieve Smith (eds.), Globalisation, Growth and Governance: Creating an Innovative Economy, Oxford University Press: Oxford: 30-49.

STEWART, F. (1978) Technology and Underdevelopment. Macmillan: London.

ORSENIGO, L. (1993), 'The dynamics of competition in a science-based technology: the case of biotechnology', in D. Foray and C. Freeman (eds.), Technology and the Wealth of Nations: The Dynamics of Constructed Advantage, Pinter: London: 41-65.

PEREZ, C. (1985), 'Microelectronics, long waves and world structural change: New perspectives for developing countries', World Development, 13, 3: 441-63.

PORTER, M. (1990) The Competitive Advantage of Nations. Free Press: New York.

RUIZ, R. (1997), 'The restructuring of the Brazilian industrial groups between 1980 and 1993', CEPAL Review, 61: 167-186.

SOETE, L. (1985), 'International diffusion of technology, industrial development and technological leapfrogging', World Development, 13, 3: 409-22.

UNCTAD, (1999), Handbook of International Trade and Development Statistics: 1996/1997. UN: New York.

UNIDO (1992), Industry and Development: Global Report 1992/93. UNIDO: Vienna.

WADE, R. (1990), Governing the Market: Economic Theory and the Role of Government in East Asian Industrialisation. Princeton University Press: Princeton.

WHITLEY, R. (1992), Business Systems in East Asia: Firms, Societies and Markets. Sage: London. 